\title{
Pericyte Coverage Measurement
}

National Cancer Institute

\section{Source}

National Cancer Institute. Pericyte Coverage Measurement. NCI Thesaurus. Code C114792.

The determination of the percentage of a blood vessel that is comprised of pericyte processes or cell bodies. 